\title{
Alberta making strides in mixedwood management
}

\author{
by Gitte Grover ${ }^{1}$ and Willi Fast ${ }^{2}$
}

\begin{abstract}
Driven by issues of economics, productivity, biodiversity and climate change, mixedwood management is becoming increasingly attractive. For silviculture to embrace and capitalize on natural stand dynamics, complex processes and interactions must be understood. To facilitate focused, applied research, ten Alberta forest companies have joined forces to cooperatively advance the science and management of boreal aspen/white spruce mixedwood forests. Members of the Mixedwood Management Association have committed collective research funds to develop and test practices that will sustain fibre supply, biodiversity, social and ecological values in Alberta's mixedwood forests. Forest industry members include Ainsworth Engineered Canada LP., Alberta-Pacific Forest Industries Inc., Canadian Forest Products Ltd., Daishowa-Marubeni International Ltd., Footner Forest Products Ltd., Millar Western Forest Products Ltd., Tolko Industries Ltd., Slave Lake Pulp/Alberta Plywood Ltd., Vanderwell Contractors (1971) Ltd. and Weyerhaeuser Company Ltd. The Alberta government and the University of Alberta are supporting partners in the Association. The Association's goals are to increase knowledge of aspen/white spruce mixed forests in the areas of growth and yield, crop planning, monitoring, understory protection and decision support tools. This paper highlights some of the Association-sponsored research projects.
\end{abstract}

Key words: Alberta, Mixedwood Management Association, research, growth and yield, crop plans

\section{RÉSUMÉ}

À la lumière des enjeux économiques et des questions de productivité, de biodiversité et de changements climatiques, l'aménagement des forêts mélangées est devenu de plus en plus attrayant. De façon à ce que la sylviculture puisse saisir avantage et tirer profit de la dynamique des peuplements naturels, les processus et les interactions complexes qui s'y opèrent doivent être étudiés. Pour faciliter la recherche appliquée précisément dans ce domaine, dix entreprises forestières de l'Alberta ont réuni leurs forces pour faire progresser conjointement le domaine et l'aménagement des forêts mélangées nordiques composées de tremble et d'épinette blanche. Les membres de l'Association d'aménagement des forêts mélangées ont engagé des fonds collectifs de recherche pour développer et tester des pratiques qui verront à la durabilité de l'approvisionnement en fibre, de la biodiversité et des valeurs sociales et écologiques des forêts mélangées de l'Alberta. Les membres de l'industrie forestière sont Ainsworth Engineered Canada LP., Alberta-Pacific Forest Industries Inc., Canadian Forest Products Ltd., Daishowa-Marubeni International Ltd., Footner Forest Products Ltd., Millar Western Forest Products Ltd., Tolko Industries Ltd., Slave Lake Pulp/Alberta Plywood Ltd., Vanderwell Contractors (1971) Ltd. and Weyerhaeuser Company Ltd. Le gouvernement de l'Alberta et l'Université de l'Alberta sont des partenaires de l'Association. L'objectif de l'Association est de faire progresser les connaissances sur les forêts mélangées constituées de tremble et d'épinette blanche notamment pour ce qui est de la croissance et du rendement, de la planification des coupes, de la surveillance des peuplements, de la protection du sous-étage et des outils d'aide à la décision. Cet article souligne quelques-uns de projets commandités par l'Association.

Mots clés : Alberta, Association d’aménagement des forêts mélangées, recherche, croissance et rendement, plans de coupe

\section{Introduction}

The boreal mixedwood forest is comprised mainly of aspen, balsam poplar, birch, white spruce, pine and balsam fir on upland sites, and black spruce and larch on lowland sites. The majority of upland sites grow aspen, balsam poplar and white spruce in various combinations from pure, single-species stands to intricate mixes. Species compositions in mixed stands vary spatially and are dynamic, changing by succession through the life of a stand.

After a stand-replacing fire, the more aggressively regenerating deciduous component usually suckers back from the roots, whereas white spruce seeds more slowly into available microsites and grows in the understory. Because white spruce is shade-adapted, it can grow successfully under the aspen canopy and can take advantage of the aspen as a nurse crop, i.e., competition from grasses and shrubs is reduced, relative humidity increases, seedlings are protected from late spring frosts, wind and hail, and the occurrence of terminal weevil and spruce budworm are reduced. The shorter-lived aspen component eventually declines, allows white spruce into the canopy and creates a mixed stand. White spruce will eventually dominate the stand in the climax phase of succession.

\footnotetext{
${ }^{1}$ Chair, Mixedwood Management Association; Mixedwood Management Forester, Alberta-Pacific Forest Industries Inc., Box 8000, Boyle, Alberta T0A 0M0. E-mail: gitte.grover@alpac.ca

2 Scientific Director, Mixedwood Management Association; The Forestry Corp., \#101, 11710 Kingsway Avenue, Edmonton, Alberta T5G 0X5.E-mail: willi_fast@forcorp.com
} 
Although there is increasing understanding and awareness of the productivity and ecological values of mixed species forests, current legislation in Alberta limits silvicultural options for regenerating mixed forests. Stocking standards and the requirement that white spruce be Free-To-Grow by year 14, (i.e., spruce is growing in a competition free circle), do not allow for the development of a variety of mixedwood crop plans. Rather, the silviculturist is limited to growing aspen and white spruce in spatially distinct arrangements. A current government policy, initiated by Alberta Sustainable Resource Development, requires forest companies to develop Alternative Regeneration Standards specific to their areas of forest tenure. This is an opportunity for creating standards that allow for regenerating mixedwood stands.

Mixedwood management, a new paradigm, is striving to understand the complex interactions and dynamics of mixedwood stands, and to develop forest management practices that capitalize on these natural principles. Mixedwood management contemplates silviculture that embraces natural stand dynamics and that facilitates regenerating mixedwood stands so as to maintain biodiversity and realize benefits in productivity. Mixedwood management will also provide valuable tools for growing healthy forests under a climate change scenario. In environments projected to be more difficult for current forest stand complexes to thrive, white spruce will benefit from an aspen nurse crop that will moderate temperature extremes and help prevent sun scalding, photoinhibition and desiccation. White spruce seedlings will be grown with regenerating aspen or underplanted in aspen stands nearing maturity. Harvesting techniques that deal with these multi-strata stands, (i.e., harvesting the aspen canopy while protecting the immature white spruce understory), have been developed and are currently deployed in naturally occurring multi-strata stands. For foresters who anticipate climate change anomalies that include higher temperatures, drying winds or lack of snow cover and moisture, these tools will help to lessen climate change impacts and ensure future forest health.

The Mixedwood Management Association (MWMA) is a group of ten Alberta forest companies that have joined forces to cooperatively advance the science and management of boreal white spruce/aspen mixedwood forests. Members of the MWMA have committed collective research funds to develop and test practices that will sustain fibre supply, biodiversity, social and ecological values in Alberta's mixedwood forests.

The Association provides funding for the creation and application of new knowledge for the day-to-day management of mixedwood forests. As an industry-driven group, the MWMA sets priorities for development of tools and dissemination of information that enables members to more effectively manage the forest resource.

Forest industry members include Ainsworth Engineered Canada LP., Alberta-Pacific Forest Industries Inc., Canadian Forest Products Ltd., Daishowa-Marubeni International Ltd., Footner Forest Products Ltd., Millar Western Forest Products Ltd., Tolko Industries Ltd., Slave Lake Pulp/Alberta Plywood Ltd., Vanderwell Contractors (1971) Ltd. and Weyerhaeuser Company Ltd. Alberta Sustainable Resource Development's Land and Forest Division and the University of Alberta are supporting partners in the Association. The University of
Alberta acts as a coordinating body for the MWMA, providing facilities and administrative, accounting and project management support, as well as scientific guidance to the Association.

\section{MWMA Goals and Objectives}

The MWMA has the following objectives for the support of research projects and/or Association activities:

1. Support the development of defensible, ecologicallybased (e.g., that account for the effects of succession), site-specific yield curves for:

- Fire-origin stands with or without management interventions

- Post-harvest regenerated stands across a range of potential management interventions

2. Development of defensible site-specific crop plans that lead to mixedwood stands in:

- Fire-origin stands with management interventions

- Post-harvest regenerated stands across the range of potential management interventions

3. Development and use of standardized monitoring protocols to:

- Validate yield predictions

- Address knowledge gaps for goals 1 and 2

4. Identify opportunities and techniques for management of understory spruce:

- Select hardwood stands that will allow for the successful establishment and growth of understory spruce

- Facilitate assignment of understory spruce to appropriate yield trajectories

- Develop stand selection criteria for understory spruce protection treatments and predict stand development

5. Development of decision-support tools and models for crop plan development:

- Regeneration models and growth models

\section{Current Projects}

Although the MWMA is supporting many projects to further above outlined goals, three major projects currently funded by the MWMA are highlighted below.

\section{Dynamic Aspen Density Experiment}

In collaboration with Dr. Victor Lieffers, University of Alberta, and Alberta Sustainable Resource Development (SRD), the MWMA has initiated a Dynamic Aspen Density Experiment. This project is funded by the MWMA and Forest Resource Improvement Association of Alberta (FRIAA) open funds.

Despite recognizing the potential benefits of regenerating mixedwood forests where trembling aspen and white spruce grow in close proximity to one another, Alberta practitioners generally do not design regeneration treatments to promote aspen and spruce establishment in spatially intimate arrangements. As stated above, there are various factors that have been important in determining how silviculturists regenerate mixedwood forests. These include:

- Current Alberta regeneration standards demand that regenerating spruce trees be assessed as growing in freedom from aspen competition (i.e., free-to-grow) by year 14 after establishment. 
- There is insufficient understanding of the beneficial and competitive dynamics of aspen and spruce growing in close proximity, and if those dynamics change over time.

- Practitioners are unwilling to carry the risk of conifer crop failure (as determined by the current Regeneration Standards) that is perceived to be significant if aspen and spruce are grown in intimate mixtures.

The result is that the current state of the art for growing aspen and spruce mixedwoods is to promote pure spruce plantations on some portions of harvested areas while the remaining portions of cutblocks are allowed to regenerate to pure aspen with hopes that the resulting proportions of aspen and spruce are sufficient to grow the timber required to support annual allowable cuts. The continuation of this approach to mixedwood regeneration will result in a highly aggregated (patchy) distribution of tree species across the managed forest landscape with unknown but likely negative effects on timber production, habitat quality and biodiversity values.

Depending on various stand attributes (species composition, density, spatial arrangement, tree sizes, etc.), the relationship between trembling aspen and white spruce in mixedwood stands can range from symbiotic (where one or both species benefit from one another) to commensal (essentially neutral) to competitive (detrimental to at least one species). Beneficial impacts known to occur when spruce is regenerated under aspen include:

- protection from frost,

- decreased winter desiccation,

- amelioration of weevil strike, and

- improved nutrient cycling through aspen leaf litter fall.

Competitive impacts include:

- attenuated light transmission through overtopping aspen canopies,

- physical abrasion of spruce by overtopping aspen, and

- below-ground competition for moisture and nutrients.

Currently, mixedwood stand dynamics are not sufficiently understood so as to be able to determine the kinds of stand structures that produce symbiotic, commensal, and competitive conditions at various stages of stand development. If that understanding can be improved, new prescriptions for growing mixedwoods in intimate mixtures become possible. These prescriptions would be compatible with the concept of crop planning where stands would be actively managed to conform to prescribed stand conditions (differing at various stages of stand development) designed to achieve explicitly defined (timber volume) objectives.

Because the thresholds that determine competitive status are likely not constant through successive stages of stand development, traditional density trials are not appropriate for determining what those thresholds are and how they change through time. Rather, dynamic density experiments are required where various competitive densities are tested in each of several stand development stages.

The objectives of the experiment are to:

1. Identify the thresholds in aspen density that determine stand condition (symbiotic, commensal, competitive as previously described) during each of two stand development Stages (17 and 22 years of age).
2. Determine the survival and growth of spruce and aspen in different stand conditions during each of two stand development stages.

3. Determine the opportunity cost to aspen production of optimizing spruce survival and growth.

4. Provide credible data with which to develop sciencebased Alternative Regeneration Standards for mixtures of spruce and aspen.

Leading Alberta scientific authorities and silviculture practitioners have been engaged for the development of this experiment. The project will establish 120 Permanent Sample Plots (PSPs) in 20 cutblocks across Alberta where spruce and aspen are growing together and where specified experimental density treatments will have been undertaken. Spruce and aspen survival, growth, and competitive interactions will be assessed annually for five years.

Results from the experiment will be used to:

1. Estimate the aspen density thresholds that determine competitive stand condition in each of two stand development stages.

2. Develop mixedwood crop plans that achieve management objectives for spruce and for aspen.

3. Develop Alternative Regeneration Standards based on empirical evidence.

4. Improve Alberta's currently evolving growth and yield projection models (Mixedwood Growth Model (MGM) and Growth and Yield Projection System (GYPSY)).

Field installations are expected to commence in summer of 2007.

\section{Adapting the Mixedwood Growth Model (MGM) for post-harvest and managed stands}

This project is supported by FRIAA open funds, the MWMA and Western Boreal Growth and Yield Association (WESBOGY). The principal investigator and project leader are Drs. Phil Comeau and Mike Bokalo, University of Alberta, respectively. Dr. Ken Stadt was hired full-time by the MWMA as a research professor to undertake many of the analyses.

The Mixedwood Growth Model (MGM) is a distanceindependent, individual-tree, growth projection model developed by Dr. Steve Titus at the University of Alberta. It has been developed and calibrated for modeling the growth of fully stocked, natural-origin white spruce, aspen, lodgepole pine and mixedwood stands in western Canada. Further development is required to improve simulations of stand growth following harvesting by traditional or alternative silvicultural practices.

Government and industry sampling programs now contain up to 20 years of repeated measurements for natural, managed and post-harvest stands, which can be utilized in model refinements for young stand growth. Since long-term growth and yield data or predictions are not currently available for silvicultural practices in boreal mixedwood stands, process-oriented modeling must be used to estimate or adjust tree survival and growth rates based upon the availability of critical resources (i.e., light). This approach has been utilized in many other models and is reliable for silvicultural practices provided that key factors or processes are adequately represented. 
MGM currently provides optimistic estimates of stand yield since it is based primarily upon data from the Alberta Permanent Sample Plot (PSP) program. PSP sampling is biased toward fully stocked stands and does not reflect the patchiness and variability in stand volumes found across the landbase. Therefore, volume loss factors applicable to Alberta should be developed to provide more realistic growth and yield estimates for maturing stands.

This project is designed to incorporate into MGM the flexibility and functions that are needed to model and assess growth and yield implications of current and future forest management strategies and silvicultural prescriptions in Alberta's boreal mixedwood forests.

It is proposed to add new functionality and capabilities to MGM through:

- Improving the representation of early tree and stand growth using newly available juvenile stand data that will:

a) Improve existing growth and mortality functions for trees in natural stands

b) Add the capacity to model post-harvest and treated natural stands.

- Modifying the architecture of MGM to permit incorporation of process-oriented functions and to provide flexibility for modeling a range of current and future silvicultural practices.

- Developing and enhancing the capability of MGM for predicting the response of mixedwood stands to silvicultural practices, especially understory protection, using a combination of empirical and process-oriented modeling approaches. A semi-spatial approach, modeling multiple strata (such as white spruce understory protection harvests that use machine corridors, aspen overstory removal area and residual area where aspen was retained) and their interactions with each other will be taken.

- Develop volume loss factors (VLF) to adjust model predictions when they are applied to a stand rather than plot level. The volume loss factor will be developed through field sampling of sub-polygons within discrete Alberta Vegetation Inventory (AVI) polygons to determine their heterogeneity in terms of density and volume.

The main product of this work will be a new version of MGM with enhanced capability for forest growth projections following harvesting and management interventions. This project will facilitate forest planning under enhanced forest management, allowing the development of strategies for increased productivity (e.g., overlapping aspen and spruce rotations) and more ecologically sensitive management (e.g., mixed-species forestry). As in the past, a compiled, userfriendly version of the model and manual will be freely available to the public, forest managers, regulators, and researchers as downloadable files from the MGM Web site (http://www. rr.ualberta.ca/research $/ \mathrm{mgm} / \mathrm{mgm}$.htm) at no charge.

The new version of MGM is expected to be released in June, 2007.

\section{Alberta Silviculture Guide}

The Alberta Silviculture Guide is funded through the MWMA and FRIAA open funds. Scott Formaniuk, Coast to Coast Reforestation; Milo Mihajlovich, Incremental Forest
Technologies Ltd.; and John Beckingham, Geographic Dynamics Corp. are developing the Guide with input from subject matter experts and practitioners.

The Alberta Silviculture Guide presently focuses on Mixedwood management of aspen and white spruce complexes, but will be expanded in the future to encompass all commercial boreal forest species. The Guide has taken a unique approach in that it offers practitioners a suite of tools to aid in making silviculture decisions. It is comprised of three distinct components:

1. The Knowledge Management System

2. The Desk Reference

3. The Field Guide or Tools

A Decision Capture and Tracking Process provides the system that directs practitioners through the series of choices that they will have to make when formulating a silviculture prescription. It does not prescribe choices, but rather acts as a bookkeeping system that allows practitioners to capture and track their decisions and to see how the choices they make affect their future silviculture options.

The Knowledge Management System is the foundation upon which the guide is built. It contains the digital source information (where possible) and the references that are used to develop the Desk Reference and the Field Guide. The Knowledge Management System has been developed in a database format that catalogues and assesses the knowledge used in the development of the guide in terms of both reliability and applicability. Where possible, direct hotlinks to the actual digital PDF reference documents used in the guide development allow the users to review source material directly. The Knowledge Management System has been developed in the commonly available Access Database format.

The Desk Reference is the heart of the guide and it synthesizes the information and knowledge from scientific sources that are found within the Knowledge Management System. The Desk Reference is in essence the detailed writing that supports the tools in the Field Guide by providing clarification, rationale, and discussion around the silviculture knowledge and sources that are used to develop the tools. The Desk Reference also provides detailed information on interpretation of various site factors.

The Field Guide is comprised of tools that assist practitioners in preparing silviculture prescriptions. The tools have been organized into three categories for delivery:

1. Assessment tools, which provide the common methodology and language for assessing important variables that drive the interpretation and management tools.

2. Interpretation tools, which provide guidance to practitioners as to what variables are important to consider depending upon their management objectives.

3. Management tools, which provide guidance to practitioners as to what management (including establishment) options are available to them to ameliorate unfavourable conditions affecting their management objective.

The various tools within each category are used within a decision capture and tracking system that allows practitioners to select the most rational silviculture options available to them given various site-controlling factors and their own individual silviculture objectives. The tools are not prescriptive in nature but provide the practitioners information and direction on how to make decisions as they work towards 
their desired stand composition objective for various sites. The tools simply support the practitioners as they work through the decision-making process of formulating silviculture prescriptions. The following tools are being developed:

- Site Assessment Tool

- Including moisture regime and nutrient regime tool

- Plant Community Assessment Tools

- Including a competition index tool calculator, a light threshold tool and Lorimer's competition index tool

- Insect and Disease Assessment and Interpretation Tools

- Site Interpretation Tool

- Plant Community Interpretation Tools

- Integrated with Plant Community Assessment Tools

- Charts have been developed that allow practitioners to see the effect of various competition levels on crop trees and then develop personal threshold levels based on objectives or risk tolerance.
- Site Factor Management Tool

- Including Propagule Selection Tool

- Plant Community Management Options

The Guide is expected to be completed in September, 2007.

\section{Other projects}

There are a number of other projects supported by the MWMA, many of which will provide additional information for the Silviculture Guide and future enhancements to MGM. A summary of all projects supported by the MWMA can be found on their Web site http://www.mwma.rr.ualberta.ca/. For further information, please contact Stacy Bergheim, MWMA administrator, University of Alberta at (780) 4929092, Stacy.Bergheim@afhe.ualberta.ca; Willi Fast, MWMA Scientific Director, The Forestry Corp at (780) 452-5878, Willi_Fast@forcorp.com; or Gitte Grover, MWMA Chair, Alberta-Pacific Forest Industries Inc. at (780) 525-8349, gitte.grover@alpac.ca. 